\title{
Apresentação ao Dossiê Movimentos Sociais e Meio Ambiente
}

É com imenso prazer que trazemos a público o dossiê Movimentos Sociais e Meio Ambiente. A ideia de organizar um dossiê que concentrasse trabalhos focados na interrelação entre seres humanos e natureza se origina na percepção de uma demanda social improtelável. As dinâmicas humanas de apropriação do que convencionamos chamar de recursos naturais têm transformado as próprias relações sociais.

Agradecemos a Revista Brasileira de História \& Ciências Sociais pela oportunidade de apresentar ao seu público leitor um dossiê que congrega trabalhos acadêmicos de qualidade e comprometidos com as urgentes demandas da sociedade. Agradecemos, ainda, às autoras e autores que submeteram seus trabalhos, fruto de pesquisas que foram desenvolvidas nos mais diversos âmbitos da vida acadêmica oriundos de diferentes regiões deste país e do exterior.

O dossiê Movimentos sociais e Meio Ambiente foi gestado por dois historiadores que percebem o valor da interdisciplinaridade na pesquisa tanto dos movimentos sociais, quanto na temática ambiental. Os trabalhos aceitos para publicação, depois da avaliação cega por pares, são fruto de arranjos interdisciplinares que exprimem a atual encruzilhada científica que está posta pela crise ambiental, uma vez que a vida em todas as suas tonalidades não respeita as fronteiras criadas pela ciência.

Destacamos que, apesar da crise ambiental afetar a todos os seres humanos, há de se ponderar sobre a forma com que os mais diversos grupos são prejudicados. As populações mais pobres acabam ocupando áreas sujeitas aos mais variáveis riscos ambientais, e, dessa forma, os resultados da produção de riqueza não são divididos universalmente. Há, portanto, uma heterogeneidade dos problemas oriundos desta crise e que toca sujeitos e territórios de maneiras diversas. De forma equivalente, há uma pluralidade de lutas e formas de resistência no contexto latino americano contemporâneo.

A presente edição (2020/1) tem a função de trazer exemplos destas formas de organização e luta social em face ao maior desafio que a espécie humana já enfrentou. Os trabalhos dão conta de questões que vão dos movimentos indígenas 
no Brasil até a falta de esperança expressa pelas obras distópicas do final do século XX. As mais diversas lentes (gênero, patrimônio cultural, decolonialidade, emancipação política, associativismo, direito à existência) são usadas para avaliar condições de vulnerabilidade, estratégias de articulação social e enfrentamento da atual crise ambiental.

O primeiro trabalho é dos organizadores do Dossiê, Alfredo Ricardo Silva Lopes e Mario Marins Viana Junior. O Antropoceno como Regime Historicidade avalia que a velocidade com que os seres humanos têm se apropriado de outros seres e elementos naturais resulta numa nova forma de compreender o tempo. Diferente da ideia progressiva e crescente estabelecida com a Revolução Industrial e Revolução Francesa, o tempo é agora materializado pelos limitados recursos naturais restantes. E a degradação do planeta é o cronômetro que marca a possível extinção humana e provoca a história e a historiografia em desafios teórico-metodológicos.

Em Os Movimentos Indígena e Ambientalista sob o viés de análise da História Ambiental: a repercussão no Ensino de História, Poliene Soares dos Santos Bicalho, Maria de Fátima Oliveira e Fernanda Alves da Silva Oliveira discutem as interrelações entre os movimentos indígena e ambientalista no Brasil. A preocupação com a natureza é avaliada nos diferentes grupos a partir dos discursos nos livros didáticos, tendo como objetivo a temática da preservação do meio ambiente.

Ayelen Dichdji analisa a percepção pública dos primeiros conflitos ambientais na Patagonia Argentina a partir da década de 1980 em Movimientos socioambientales, decolonialidad e historia ambiental en los conflictos patagónicos en Argentina (1980-2003). A autora avalia o surgimento da opinião pública sobre a exploração dos recursos naturais, através das páginas dos periódicos Clarín e La Nacion.

A Região Amazônica teve e tem marcada em todo seu processo histórico uma pluralidade de anseios de diversas fontes. Nesse contexto, Fabiane Araujo Oliveira e Elizabeth Conceição Santos examinam as memórias do processo de ocupação da Área de Proteção Ambiental Floresta Manaós (localizada na zona Centro-sul da cidade de Manaus-AM). Em A História Ambiental da APA Floresta 
Revista Brasileira de História \& Ciências Sociais - RBHCS

Vol. $12 \mathrm{~N}^{\circ} 23$, Janeiro - Junho de 2020

Manaós: um movimento pela defesa territorial e a emersão da Ciência Ambiental foi observada a complexidade nos embates entre os mais diversos atores interessados na preservação do ambiente.

Alicia Ferreira Gonçalves evidencia em Mapas Sociais: Subsídios para a elaboração do Plano de Gestão Territorial e Ambiental potiguara a importância da produção de mapas sociais pelos indígenas Potiguara para gestão do próprio território. Nas observações da pesquisadora, a elaboração do Plano de Gestão Territorial e Ambiental (PGTA) fortalece a autonomia na gestão dos territórios indígenas em consonância com a proteção do ambiente.

Em Movimento Social de Pescadores e Pescadoras Artesanais em Mato Grosso: Patrimônio Cultural e Lutas Políticas, Manuela Areias Costa e Luciano Pereira da Silva trazem reflexões sobre o movimento dos pescadores e pescadoras artesanais, o meio ambiente e o patrimônio cultural imaterial. Na avaliação dos autores as políticas públicas para pesca que restringem o uso de utensílios comunalmente apropriados pelas pescadoras e pescadores colocam em risco o direito ao trabalho e a reprodução cultural do grupo.

A mobilização social das mulheres no Movimentos dos Atingidos por Barragens (MAB) é estudada por Monise Vieira Busquets, em Bordando a Luta: o Coletivo de Mulheres do Movimento dos Atingidos por Barragens e as oficinas de Arpilleras como estratégia de mobilização social. A partir das reflexões das militantes e idealizadoras do projeto "Arpilleras, Bordando a Resistência" a autora destaca a resistência e organização como parte central da vida dessas das mulheres.

Eunápio Dutra do Carmo discute como o campo político da cidade de Barbacena-PA foi recomposto em função da mineração. Em Contra-informação e conhecimento emancipatório como práticas educativas no enfrentamento da economia de desastres da mineração em Barcarena (PA) o autor analisa atuação dos movimentos sociais na produção social da contra-informação no contexto da economia de desastre, no intuito de romper com a percepção tecnicista dos desastres.

Para avaliar o contexto do surgimento das associações ambientalistas, Olivia Cristina Perez destaca que as associações ambientais em Santos-SP surgem, em sua maioria, após os anos 2000. Em Relações entre Estado e 
Revista Brasileira de História \& Ciências Sociais - RBHCS

Vol. 12 No $^{\circ}$, Janeiro - Junho de 2020

associações: origens de associações ambientais em Santos (SP) fica evidente o papel do financiamento estatal para o financiamento das fundações privadas e associações sem fins lucrativos no Brasil.

Gustavo Seferian busca, a partir da tradição marxista no direito, evidenciar o duplo caráter do direito à vida. Em O duplo caráter do direito à existência: luta de classes e articulação estrutural das contrarreformas sociais, políticas e ambientais, o autor demonstra como as contrarreformas direcionadas aos direitos sociais guardam articulação estrutural com os ataques direcionados ao meio ambiente. Avalia ainda que a contraposição incisiva dos movimentos sociais na defesa de seus interesses imediatos se aglutina às bandeiras ecológicas.

A representação da distopia ambiental no cinema é examinada por Franco Santos Alves da Silva em “O Mundo de 2020”: Relações sociais e meio ambiente na distopia de 1973. Na observação do filme "O Mundo de 2020”, (Soylent Green, no título original), o autor discorre sobre a relação da narrativa distópica com a emergência das questões geopolíticas e ambientais da década de 1970.

Em suma, o conjunto de trabalho aqui reunidos tem ainda o propósito de provocar o leitor a um duplo-movimento. Aqueles e aquelas que estão distantes do debate sobre a questão ambiental e crise na qual estamos imersos poderão compreender a amplitude dos problemas pelo convite a se aproximarem das reflexões ora apresentadas. Por outro lado, há uma interpelação mais incisiva: a de fomentar aprendizados sobre distintas formas de lutas e resistências que, neste dossiê, incluem desde o debate sobre livros, filmes, documentos oficiais, etc., até as ações diversificadas de uma massa plural de sujeitos (indígenas, pescadores, camponeses, entre outros) que enfrenta amplos e diferentes conflitos ambientais na América Latina.

O dossiê Movimentos Sociais e Meio Ambiente, portanto, é um trabalho coletivo de pesquisadoras e pesquisadores engajados e preocupados com o tempo que nos resta e com o espaço que habitamos. Boa leitura!

Prof. Alfredo Ricardo Silva Lopes

Prof. Mário Martins Viana Júnior

Fortaleza - Campo Grande / Inverno de 2020. 